\title{
Overexpression of regenerating gene la appears to reflect aberration of crypt cell compartmentalization in sessile serrated adenoma/polyps of the colon
}

Kentaro Okamoto ${ }^{1,2 \dagger}$, Takahiro Fujimori ${ }^{1 \dagger}$, Takeshi Yamaguchi ${ }^{1,2}$, Kazuhito Ichikawa', Shigeki Tomita', Tamotsu Sugai ${ }^{3}$, Johji Imura ${ }^{4}$, Yasuo Ohkura ${ }^{5}$, Takashi Yao ${ }^{6}$, Shigehiko Fujii ${ }^{7}$, Toshihiro Kusaka ${ }^{7}$, Akira Sekikawa ${ }^{8}$, Hirokazu Fukui ${ }^{9}$, Tsutomu Chiba ${ }^{10}$, Hiroyuki Kato ${ }^{2}$ and Hiroyuki Mitomi ${ }^{{ }^{*}}$

\begin{abstract}
Background: Colorectal sessile serrated adenoma/polyps (SSA/Ps) are characterized by asymmetrical distribution of Ki67-positive cells, which varies among crypts and involves the crypt length to a variable extent; the pattern has been designated as aberration of crypt cell compartmentalization. The regenerating gene (REG) la is a cell growth and/or anti-apoptotic factor and its overexpression might be associated with aberration of crypt cell compartmentalization in SSA/Ps. We investigated REG la expression in SSA/Ps in comparison to hyperplastic polyps (HPs).

Methods: A total of 64 cases of serrated polyps ( $\geq 10 \mathrm{~mm}$ in size), including 53 SSA/Ps and 11 HPs, were included in the present study. Immunostaining was performed using a labeled streptavidin-biotin method. REG la expression was classified as follows: (i) expression of endocrine cells: grade 0 (a few positive cells) to 3 (marked increase in positive cells); (ii) expression of goblet cells: grade 0 (negative) to 2 (positive for crypts and surface epithelial cells); (iii) staining intensity of goblet cells: grade 0 (negative) to 2 (strong); (iv) staining intensity of crypt (absorptive) cell membranes: grade 0 (negative) to 2 (strong). The presence of aberration of crypt cell compartmentalization was assessed using Ki67 immunostaining.

Results: With regard to the REG la expression of endocrine cells, 8 out of 11 HPs (73\%) were grade 0, whereas 51 of 53 SSA/Ps $(96 \%)$ were grade 1 or higher $(p<0.001)$. With regard to the distribution of REG la-immunoreactive goblet cells, 10 of 11 HPs (91\%) were grade 1, whereas 50 of 53 SSA/Ps (94\%) were grade $2(p<0.001)$. A similar trend was found in the staining intensity of goblet cells or crypt cell membranes $(p=0.011)$. Aberration of crypt cell compartmentalization was more frequently identified in SSA/Ps (72\%) than in HPs (18\%; $p=0.002)$. A significant association was observed between REG la overexpression and the aberration of crypt cell compartmentalization in serrated polyps ( $p=0.037)$.
\end{abstract}

Conclusions: REG la overexpression is a characteristic of SSA/Ps, which appears to reflect aberration of crypt cell compartmentalization.

Virtual slides: The virtual slide(s) for this article can be found here: http://www.diagnosticpathology.diagnomx.eu/ vs/7240956081100040

Keywords: Colon, Crypt cell compartmentalization, Hyperplastic polyp, REG la, Sessile serrated adenoma/polyp

\footnotetext{
* Correspondence: hmitomi@dokkyomed.ac.jp

${ }^{\dagger}$ Equal contributors

'Department of Surgical and Molecular Pathology, Dokkyo Medical University School of Medicine, 880 Kitakobayashi, Mibu, Shimotsuga, Tochigi 321-0293,

Japan

Full list of author information is available at the end of the article
} 


\section{Background}

In 1996, Torlakovic and Snover were the first to describe sessile-type serrated adenoma of the colon in an analysis of serrated adenomatous polyposis with the development of adenocarcinoma [1]. In 2003, Torlakovic et al. [2] refined the criteria and proposed a subclassification of colorectal serrated polyps into hyperplastic polyps (HPs), traditional serrated adenomas, and sessile serrated adenomas. The last category of serrated polyps is now designated as sessile serrated adenomas/polyps (SSA/Ps) in the fourth edition of the WHO Classification of Tumors of the Digestive System [3]. Although SSA/Ps and large HPs ( $\geq 10 \mathrm{~mm}$ in diameter), the latter was introduced by Warner et al. in 1994 [4], were synonymously used at times [5], SSA/Ps were histologically separated from large HPs [6,7]. SSA/Ps were characterized by irregular and asymmetrical distribution of Ki67-positive cells, which frequently varied among crypts and involved the crypt length to a variable extent; the pattern was designated as "aberration of crypt cell compartmentalization" [8]. This is consistent with the results of computer-assisted cytometric analysis of Ki67 immunoreactivity in SSA/Ps [6]. However, aberration of crypt cell compartmentalization was not a characteristic of large HPs as well as conventional (small) HPs $[6,7]$.

The regenerating gene (REG) I $\alpha$ protein, the human homologue of the rat REG protein, was originally isolated from regenerating pancreatic islets [9], which were immunohistochemically positive for acinar, but not from islet cells of the pancreas [10]. REG I $\alpha$ protein has been found to be expressed in normal colorectal mucosa and colorectal tumors [11]. REG I $\alpha$ is also involved in the ulcerative colitis-neoplasia sequence $[12,13]$. Previous experimental studies have shown that REG I $\alpha$ promotes cell growth and/or anti-apoptosis of cancer cells $[12,14]$.

A link between REG I $\alpha$ and $\beta$-catenin has been demonstrated in a study of liver cancer, in which $\beta$-catenin mutations induced REG I $\alpha$ expression in liver cancer cells [15]. In this context, REG I $\alpha$ expression together with aberrant $\beta$-catenin expression was associated with high Ki67 immunoreactivity in salivary gland tumors [16]. Recent studies have detected aberrant nuclear accumulation of $\beta$-catenin in SSA/Ps $[17,18]$. Wnt stimulation has been shown to lead to the inactivation of APC and the activation of $\beta$ catenin, resulting in nuclear accumulation of $\beta$-catenin, which subsequently complexes with the T-cell factor/ lymphoid enhancer factor to activate target gene transcription resulting in cell proliferation [19]. These findings suggest that activation of $\mathrm{Wnt} / \beta$-catenin signaling is associated with aberration of crypt cell compartmentalization in SSA/Ps.

The aim of this study was to investigate the expression of REG I $\alpha$ in a subset of SSA/Ps and HPs and to discuss its expression in relation to nuclear $\beta$-catenin expression and aberration of crypt cell compartmentalization.

\section{Methods}

\section{Tissue samples and histological examination}

Samples of 154 cases of serrated polyps ( $\geq 10 \mathrm{~mm}$ in size) were obtained from the Dokkyo Medical University Hospital and its affiliated institutions between 2003 and 2010. The diagnosis of SSA/P was made when a serrated lesion had two or more of the following three findings: irregularly branching crypts ( $>10 \%$ of the lesion), horizontally arranged basal crypts (inverted T- and/or Lshaped crypts) ( $>10 \%$ of the lesion), and crypt dilatation ( $>10 \%$ of the lesion), according to a previous report [6]. Serrated polyps with only one of the three findings were designated as intermediate type, and this type was included in HPs. Criteria for HP included narrow straight crypts with a normal distribution of the proliferative zone at the base of the crypts with uniform maturation and serration toward the surface [3]. Cases of mixed serrated polyps and conventional adenoma or traditional serrated adenoma were excluded. Some of the serrated polyps were excluded because of poor orientation of the specimens. Finally, a total of 64 cases of serrated polyps, including 53 SSA/Ps and 11 HPs (histologically renamed large HPs), were included in the present study. Clinicopathological characteristics of the serrated polyps studied are summarized in Table 1.

The ethics committee of the Dokkyo Medical University School of Medicine approved all protocols, and informed consent for tissue procurement was obtained from all patients. This work was conducted in a blinded manner using a linkable anonymizing method. Samples used in

Table 1 Clinicopathological characteristics of colorectal serrated polyps studied

\begin{tabular}{lcc}
\hline & $\begin{array}{c}\text { SSA/P } \\
(\mathbf{n}=\mathbf{5 3})\end{array}$ & $\begin{array}{c}\text { HP } \\
(\mathbf{n}=\mathbf{1 1})\end{array}$ \\
\hline Gender & 28 & 6 \\
Male & 25 & 5 \\
Female & $55.4(35-77)$ & $59.3(38-69)$ \\
Age (yrs) & & 1 \\
Location & 13 & 3 \\
Cecum & 16 & 3 \\
Ascending colon & 17 & 0 \\
Transverse colon & 3 & 3 \\
Descending colon & 4 & 1 \\
Sigmoid colon & 0 & $10.6(10-15)$ \\
Rectum & $13.2(10-30)$ & \\
Tumor size (mm) & &
\end{tabular}

${ }^{*}$ Age and tumor size are represented as mean (range). SSA/P: sessile serrated adenoma/polyp; HP: hyperplastic polyp. 
this study were materials obtained for diagnosis or treatment, but not for research purposes. Participation in the present study did not increase the medical disadvantage or risk for patients.

\section{Immunohistochemistry}

Immunohistochemical staining for REG I $\alpha$ and Ki67 was performed with an LSAB-2 kit (Dako, Glostrub, Denmark) as described previously $[13,20]$. In brief, $4-\mu \mathrm{m}$ sections were placed on slides, deparaffinized, rehydrated, and then pretreated with $0.3 \% \mathrm{H}_{2} \mathrm{O}_{2}$ in methanol for $20 \mathrm{~min}$ at room temperature to quench endogenous peroxidase activity. The slides were then placed in $0.01 \mathrm{ml} / \mathrm{L}$ citrate buffer ( $\mathrm{pH}$ 6.0) and treated by microwave heating (400 W, $95^{\circ} \mathrm{C}$; MI-77; Azumaya, Tokyo, Japan) to facilitate antigen retrieval.

The sections were first incubated with $1 \%$ bovine serum albumin in phosphate-buffered saline (PBS; pH 7.2) for $30 \mathrm{~min}$ and then with an anti-REG I $\alpha$ antibody (the source of the antibody is described in reference [10]; dilution 1:2,000) and anti-Ki67 antibody (DAKO; dilution 1:50) for $1 \mathrm{~h}$. Thereafter, the sections were incubated with a biotinylated secondary antibody for $15 \mathrm{~min}$, washed with PBS, and treated with peroxidase-conjugated streptavidin for $20 \mathrm{~min}$. Finally, the sections were incubated in 3, 3'-diaminobenzidine tetrahydrochloride (Liquid DAB + Substrate Chromogen System; Dako, USA) with $0.05 \% \mathrm{H}_{2} \mathrm{O}_{2}$ for $3 \mathrm{~min}$ and then counterstained with Mayer's hematoxylin.

\section{Evaluation of immunohistochemical staining}

In normal colon, REG I $\alpha$ expression is found in goblet cells and endocrine cells [13]. Furthermore, by using immunohistochemistry for chromogranin A, REG I $\alpha$ has been confirmed to be present exclusively in endocrine cells [21]. REG I $\alpha$ positive endocrine cells are pyramidally shaped and closed with a broad base that directly abuts the basement membrane. We therefore classified the expression of REG I $\alpha$ in a semiquantitative method according to the following scheme: (i) expression of endocrine cells: grade 0 , a few $(<1 \%$ of crypt cells) positive cells at the bottom of the crypt; grade 1, mild increase (1-5\% of crypt cells) in the expression at the bottom of the crypt; grade 2 , moderate increase (6-10\% of crypt cells) in the expression at the bottom of the crypt and/or slight increase in the expression extending upward to surface epithelial cells; grade 3 , marked increase ( $>10 \%$ of crypt cells) in the expression in crypt and surface epithelial cells; (ii) expression of goblet cells: grade 0 , negative; grade 1, expression in crypt cells, but not in surface epithelial cells $(\leq 50 \%$ of crypt cells); grade 2, expression in crypt and surface epithelial cells ( $>50 \%$ of crypt cells); (iii) staining intensity of goblet cells: grade 0 , negative staining in goblet cells; grade 1, weak expression; grade 2, strong expression; (iv) staining intensity of crypt (absorptive) cell membranes: grade 0 , negative expression in any epithelial cell membrane; grade 1 , weak membranous expression; grade 2, strong membranous expression. Immunostaining was evaluated in most representative areas showing highest intensity. Representative microphotographs of REG I $\alpha$ expression are illustrated in Figure 1.

We assessed the presence of aberration of crypt cell compartmentalization using Ki67 immunostaining and applied the criteria for aberration of crypt cell compartmentalization as described by Torlakovic et al. [8] as follows: an irregular distribution of Ki67-immunoreactive cells, which frequently varied among crypts, involved the crypt length to a variable extent, and was asymmetric in each individual crypt. Aberration of crypt cell compartmentalization was considered to be present when this feature existed in more than $10 \%$ of the crypt.

Every slide was examined simultaneously by four authors (KO, TY, HM, and TF) using a multi-head microscope, without prior knowledge of the clinicopathological data. In case of disagreement in the assessment of REG I $\alpha$ expression and the presence of aberration of crypt cell compartmentalization, the slide was re-examined and consensus was reached on further review.

\section{Statistical analysis}

Categorical analysis of variables was performed using either the chi-squared test (with Yates' correction) or Fisher's exact test, as appropriate. Continuous data were compared with the Mann-Whitney $U$-test. A $p$ value of $<0.05$ was considered statistically significant. All statistical analyses were carried out using the R software (version 2.15.0).

\section{Results}

With regard to the REG I $\alpha$ expression of endocrine cells, 8 out of $11 \mathrm{HPs}(73 \%)$ were grade 0 and 51 of 53 SSA/Ps (96\%) were grades 1 to 3 ( $p<0.001)$. With regard to REG I $\alpha$ expression of goblet cells, 10 of 11 HPs (91\%) were grade 1 and 50 of $53 \mathrm{SSA} / \mathrm{Ps}$ (94\%) were grade $2(p<0.001)$; a similar trend was found in the REG I $\alpha$ staining intensity of goblet cells $(p<0.001)$. None of the HP cases showed crypt cell membrane expression of REG I $\alpha$, but 26 of 53 SSA/Ps (49\%) were positive for membranous expression ( $p=0.011$; Table 2$)$. The sum of the grading scores for the four items described above ranged from 2 - 9 (median, 6) in SSA/Ps and 2 - 4 (median, 3) in HPs; the values were significantly higher in SSA/Ps than in HPs $(p<0.001)$. The expression patterns of REG I $\alpha$ in representative cases of SSA/Ps and HPs are illustrated in Figure 2. In a case of HP, diagnosed as inverted HP by serial sections, REG I $\alpha$ expression of goblet cells was grade 2 (Figure 3 ).

Aberration of crypt cell compartmentalization was more frequently identified in SSA/Ps (38 of 53 [72\%]) than in 


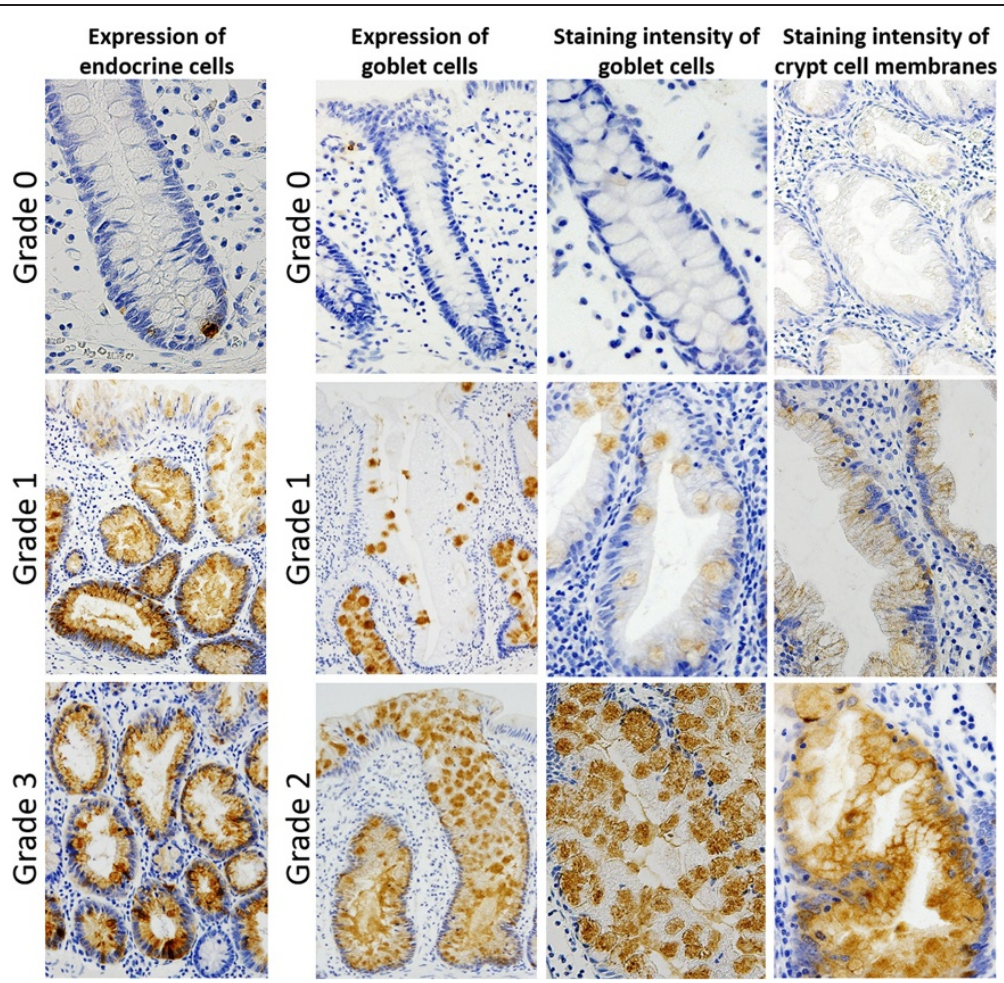

Figure 1 Immunohistochemical assessment (grading) of REG la expression.

Table 2 Immunoreactivity of REG la in SSA/Ps and HPs

\begin{tabular}{|c|c|c|c|}
\hline REG Ia expression & $\begin{array}{l}\text { SSA/P } \\
(n=53)\end{array}$ & $\begin{array}{c}\text { HP } \\
(n=11)\end{array}$ & $p$ value \\
\hline Distribution of endocrine cells & & & $<0.001$ \\
\hline Grade 0 & 2 & 8 & \\
\hline Grade 1 & 30 & 1 & \\
\hline Grade 2 & 17 & 2 & \\
\hline Grade 3 & 4 & 0 & \\
\hline Distribution of goblet cells & & & $<0.001$ \\
\hline Grade 0 & 0 & 0 & \\
\hline Grade 1 & 3 & 10 & \\
\hline Grade 2 & 50 & 1 & \\
\hline Staining intensity of goblet cells & & & $<0.001$ \\
\hline Grade 0 & 0 & 0 & \\
\hline Grade 1 & 5 & 7 & \\
\hline Grade 2 & 48 & 4 & \\
\hline Staining intensity of crypt cell membrane & & & 0.011 \\
\hline Grade 0 & 27 & 11 & \\
\hline Grade 1 & 19 & 0 & \\
\hline Grade 2 & 7 & 0 & \\
\hline
\end{tabular}

SSA/P: sessile serrated adenoma/polyp; HP: hyperplastic polyp.
HPs (2 of $11[18 \%] ; p=0.002)$. Of note, inverted HPs demonstrated aberration of crypt cell compartmentalization. In addition, we examined the association of REG I $\alpha$ expression with aberration of crypt cell compartmentalization. In a combined analysis of SSA/Ps and HPs, high REG I $\alpha$ expressors (sum of the grading score $\geq 5$ ) were more frequent in serrated polyps with aberration of crypt cell compartmentalization (37 out of 40 [93\%]) than in those without (14 out of 24 [58\%]; $p=0.037$ ).

We performed an ancillary immunohistochemical study of $\beta$-catenin (monoclonal antibody, Transduction Laboratories, Lexington, KY; dilution 1:2,000) in a case of SSA/P (Figure 4). In this case, nuclear and cytoplasmic expression of $\beta$-catenin was evident at the bottom of the crypt, similar to REG I $\alpha$.

\section{Discussion}

This is the first report to analyze REG I $\alpha$ expression and crypt cell compartmentalization in serrated polyps. We show that REG I $\alpha$ overexpression is a characteristic of SSA/Ps, as compared to (large) HPs. In analyses of ulcerative colitis-associated neoplasia, the expression of REG I $\alpha$ gradually increased from regenerative mucosa through low-grade dysplasia to high-grade dysplasia; in this sequence, the distribution of proliferative cells increased similar to the REG I $\alpha$-positive region $[12,13]$. In addition, REG I $\alpha$-positive pleomorphic adenoma of the salivary gland demonstrated a significantly higher 

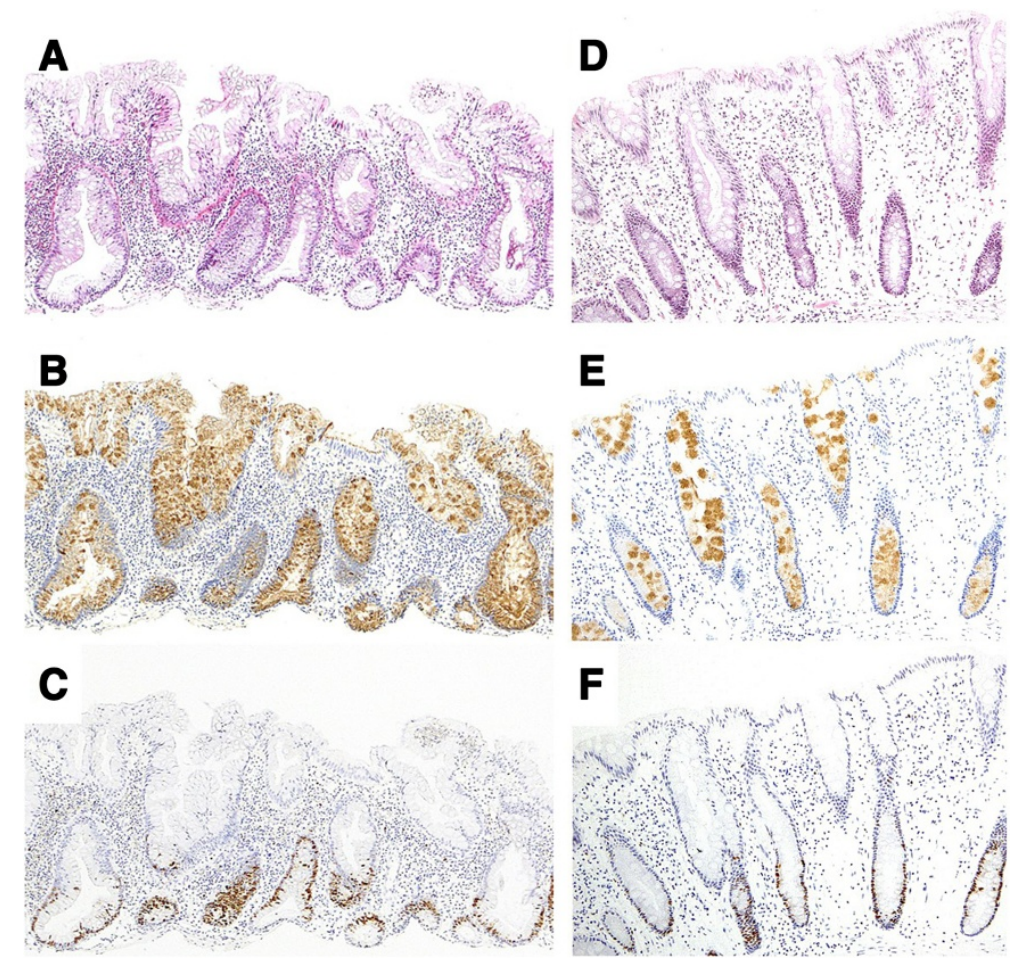

Figure 2 Histology and immunohistochemistry for REG la and Ki67 of SSA/P and HP. (A) SSA/P showing irregularly branching crypts,

horizontally arranged basal crypts, and crypt dilatation (hematoxylin \& eosin); (B) REG la is mainly expressed in goblet cells in the entire crypt and surface epithelium in SSA/P (immunoperoxidase); (C) Ki67-immunoreactive cells in SSA/P are either increased or decreased or both, with irregular distribution; (D) HP represents narrow-shaped crypts without luminal serration in the basal part (hematoxylin \& eosin); (E) REG la is weakly and sparsely expressed in goblet cells in HP (immunoperoxidase); (F) Ki67-immunoreactive cells are distributed regularly in the basal part of crypts in HP.
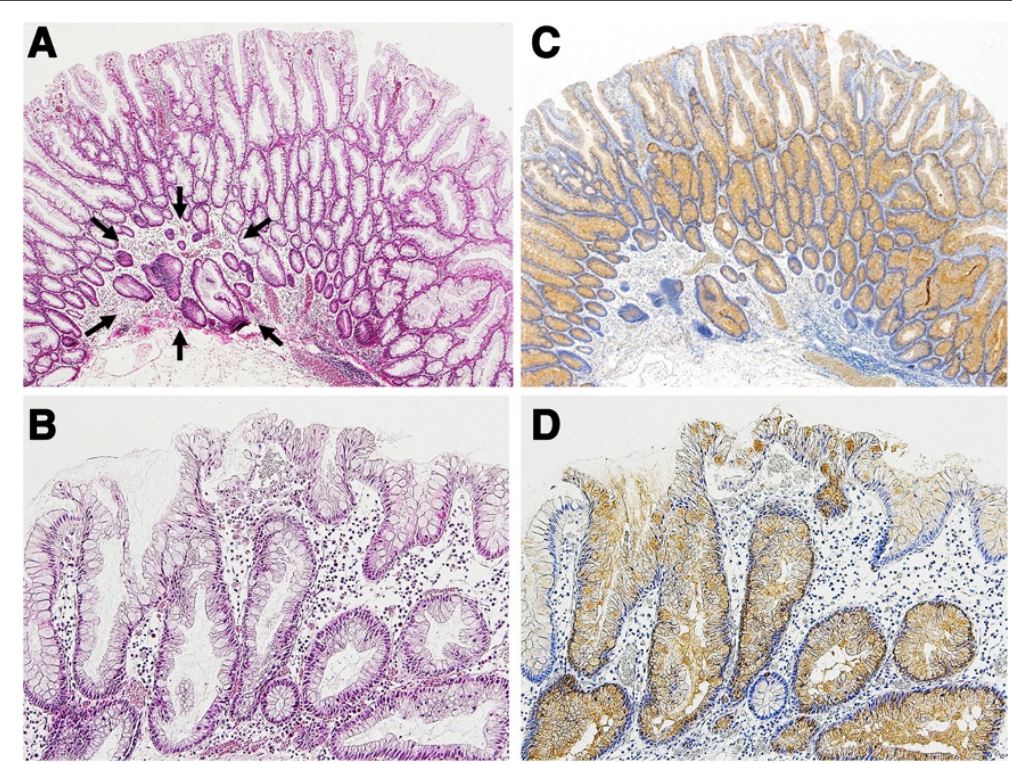

Figure 3 A case of inverted HP in the ascending colon. (A) Epithelial misplacement into the submucosa (arrows); (B) micropapillary projection at the surface area; (C) diffuse positivity for REG la in misplaced glands of the submucosa as well as in all glands of the mucosa; (D) REG la positivity representing goblet cells in the surface epithelium. 


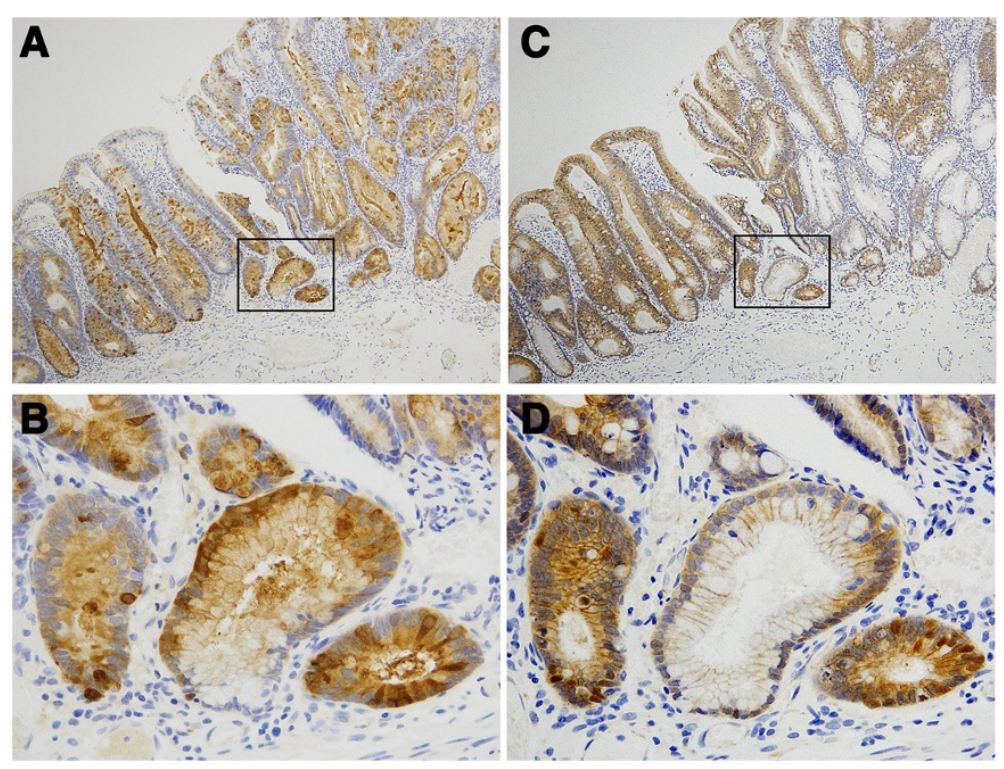

Figure 4 Expressions of REG la and $\boldsymbol{\beta}$-catenin in serial sections of a case of SSA/P. (A) Diffuse REG la expression observed in the whole crypt cell population and surface epithelial cells; (B) strong cytoplasmic REG la staining mainly in cells at the bottom of the crypt (magnifying view of 'box' in figure $\mathbf{A}$ ); (C) $\beta$-catenin is expressed mainly in the cell membrane, except at the bottom of the crypt; (D) note expression of nuclear and cytoplasmic $\beta$-catenin at the bottom of the crypt, similar to REG la (magnifying view of 'box' in figure $\mathbf{C}$ ).

Ki67 labeling score than those negative for REG I $\alpha$ [16]. In previous reports, SSA/Ps demonstrated high proliferative activity with asymmetric localization of proliferative cells [6-8]. This observation is in line with our results that aberration of crypt cell compartmentalization was more frequently identified in SSA/Ps (72\%) than in HPs (18\%). We also found a significant association between REG I $\alpha$ overexpression and aberration of crypt cell compartmentalization in serrated polyps. In normal colonic crypts, endocrine cells and Paneth cells exist, in general, in proliferative and intermediate regions, and goblet cells are present only in the intermediate region [19]; however, in SSA/Ps, numerous goblet cells are identified at the base of the crypts (proliferative region) as well as in the intermediate region [2]. In SSA/Ps, there are abnormalities in the location of the various compartments (previously referred to as abnormal proliferation or dysmaturation [2]), a feature that Torlakovic et al. designated as the aberration of crypt compartmentalization [8].

Interestingly, we found that REG I $\alpha$-expressing endocrine cells are increased in SSA/Ps. To our knowledge, endocrine cell hyperplasia has not been previously described in the context of SSA/Ps. In microvesicular-type $\mathrm{HP}$, the number and/or size of endocrine cells are increased and they are mainly found in the intermediate region of the crypts [2]. Recently, Naert et al. reported a case of large cell neuroendocrine carcinoma arising in an SSA [22]. Corresponding to this case and our findings, REG I $\alpha$ is thought to be associated with endocrine cell hyperplasia and the development of neuroendocrine tumors in SSA/Ps. Mutations in REG I $\alpha$ were identified in patients with carcinoid tumors [23], suggesting a link between its gain-of-function mutation and endocrine cell hyperplasia.

In our ancillary study, REG I $\alpha$ positivity was related to aberrant (non-membranous type) $\beta$-catenin expression in SSA/Ps. In conjunction with this finding, aberrant $\beta$ catenin expression was related to REG I $\alpha$ positivity in pleomorphic adenoma [16]. A link between REG I $\alpha$ and $\beta$-catenin has been demonstrated in a study of liver cancer, in which $\beta$-catenin mutations induced REG I $\alpha$ expression in liver cancer cells $[15,16]$. Therefore, REG I $\alpha$ may be a possible downstream target of the Wnt/ $\beta$-catenin signaling pathway. Wu et al. found aberrant nuclear labeling for $\beta$-catenin in 9 of 22 cases of SSA/Ps (41\%). In a recent study, widespread or focal nuclear accumulation of $\beta$ catenin (using an N-terminus antibody) was also identified in 14 of 35 right-sided SSA/Ps (40\%). Consequently, REG I $\alpha$ overexpression may contribute to the early activation of the Wnt/ $\beta$-catenin signaling pathway in SSA/Ps.

In the present study, we found one case of inverted HP displaying REG I $\alpha$ overexpression in the ascending colon with a maximum diameter of $15 \mathrm{~mm}$. This is the only case of HP with REG I $\alpha$ overexpression similar to SSA/Ps. Inverted HPs as first described by Sobin et al. are an unusual morphological variant of HPs that show epithelial misplacement into the submucosa [24]. Inverted HPs are located in the rectum or sigmoid colon; their mean size is $5 \mathrm{~mm}$ [25]. To date, a small number of cases of inverted HP associated with adenoma and adenocarcinoma have 
been reported [26-28]. An association of SSA/Ps with inverted HPs in addition to their ability of malignant progression remains unknown and an area of research and controversy.

\section{Conclusions}

This is the first report to demonstrate a correlation between SSA/P and REG I $\alpha$ expression. REG I $\alpha$ overexpression is a characteristic of SSA/Ps, which might be associated with aberration of crypt cell compartmentalization.

\section{Abbreviations}

SSA/P: Sessile serrated adenoma/polyp; HP: Hyperplastic polyp.

\section{Competing interests}

No financial and non-financial competing interests to declare in relation to this manuscript.

\section{Authors' contributions}

Study concept and design: TF and KO; immunohistochemical analysis: TY, KI ST and Ji; acquisition of data: SF, TK, AS and HF; analysis of interpretation of data: $\mathrm{HM}$ and $\mathrm{KO}$; drafting of the manuscript: $\mathrm{KO}, \mathrm{TH}$ and $\mathrm{HM}$; critical revision of the manuscript for intellectual content: TS, YO, TY and TC; study supervision: HK and TF. All authors read and approved the final manuscript.

\section{Acknowledgments}

We are grateful to Dr. Hiroshi Okamoto in Tohoku University Graduate School of Medicine, Sendai, Japan, for providing anti-REG la antibody. The authors thank Dr. Yasushi Sano (Endoscopy Division, Gastrointestinal Center, Sano Hospital, Kobe, Japan), Dr. Akihiko Ohta (Ohta clinic, Tokyo, Japan), Dr. Takahiro Fujii (Takahiro Fujii Clinic, Tokyo, Japan), Dr. Yasushi Oda (Oda Gl Clinic, Kumamoto, Japan) and Dr. Hideyo Goto (Hattori Gl Endoscopy and Oncology Clinic, Kumamoto, Japan) for kindly supplying the clinical data. The authors would also like to thank Chiaki Matsuyama, Ayako Shimizu, Takako Ono, Midori Katayama, Sizuka Kidate and Atsuko Kikuchi (Department of Surgical and Molecular Pathology, Dokkyo Medical University School of Medicine, Mibu, Japan) for their excellent technical assistance. This work was supported in part by a Grant-in-Aid from the Japan Society for the Promotion of Science (\#24590429 to Hiroyuki Mitomi and \#23590410 to Takahiro Fujimori).

\footnotetext{
Author details

${ }^{1}$ Department of Surgical and Molecular Pathology, Dokkyo Medical University School of Medicine, 880 Kitakobayashi, Mibu, Shimotsuga, Tochigi 321-0293, Japan. ${ }^{2}$ First Department of Surgery, Dokkyo Medical University School of Medicine, 880 Kitakobayashi, Mibu, Shimotsuga, Tochigi 321-0293, Japan. ${ }^{3}$ Division of Molecular Diagnostic Pathology, Department of Pathology, School of Medicine, Iwate Medical University, 19-1 Uchimaru, Morioka, Iwate 020-8505, Japan. ${ }^{4}$ Department of Diagnostic Pathology, Graduate School of Medicine and Pharmaceutical Sciences, University of Toyama, 2630 Sugitani, Toyama City, Toyama 930-0194, Japan. ${ }^{5}$ Department of Pathology, Kyorin University School of Medicine, 6-20-2 Shinkawa, Mitaka-shi, Tokyo 181-8611, Japan. ${ }^{6}$ Department of Human Pathology, Juntendo University School of Medicine, 3-1-3 Hongo, Bunkyo-ku, Tokyo 113-8431, Japan. ${ }^{7}$ Department of Gastroenterology, Kyoto Katsura Hospital, 17 Yamada Hirao, Nishikyo-ku, Kyoto 615-8256, Japan. ${ }^{8}$ Department of Gastroenterology and Hepatology, Osaka Red Cross Hospital, 5-30 Fudegasaki, Tennoji-ku, Osaka 543-8555, Japan. ${ }^{9}$ Division of Upper Gastroenterology, Department of Internal Medicine, Hyogo College of Medicine, 1-1 Mukogawa, Nishinomiya, Hyogo 663-8501, Japan. ${ }^{10}$ Department of Gastroenterology and Hepatology, Kyoto, University Graduate School of Medicine, Yoshida-Konoe, Sakyo-ku, Kyoto 606-8501, Japan.
}

\section{References}

1. Torlakovic E, Snover DC: Serrated adenomatous polyposis in humans. Gastroenterology 1996, 110:748-755.

2. Torlakovic E, Skovlund E, Snover DC, Torlakovic G, Nesland JM: Morphologic reappraisal of serrated colorectal polyps. Am J Surg Pathol 2003, 27:65-81.

3. Snover DC, Ahnen DJ, Burt RW, Odze RD: Tumours of Digestive System. In WHO Classification of tumours, Pathology and genetics. 4th edition. Edited by Bozman FT, Carneio F, Hruban RH, Theise N. Lyon: International Agency for Research on Cancer; 2010:160-165.

4. Warner AS, Glick ME, Fogt F: Multiple large hyperplastic polyps of the colon coincident with adenocarcinoma. Am J Gastroenterol 1994 89:123-125

5. Jass JR: Serrated adenoma of the colorectum and the DNA-methylator phenotype. Nat Clin Oncol 2005, 2:398-405.

6. Fujimori Y, Fujimori T, Imura J, Sugai T, Yao T, Wada R, Ajioka Y, Ohkura Y: An assessment of the diagnostic criteria for sessile serrated adenoma/ polyps: SSA/Ps using image processing software analysis for Ki67 immunohistochemistry. Diagn Pathol 2012, 7:59.

7. Shida Y, Ichikawa K, Fujimori T, Fujimori Y, Tomita S, Fujii T, Sano Y, Oda Y, Goto H, Ohta A, Tanaka S, Sugai T, Yao T, Ohkura Y, Imura J, Kato H: Differentiation between sessile serrated adenoma/polyp and non-sessile serrated adenoma/polyp in large hyperplastic polyp: A Japanese collaborative study. Mol Clin Oncol 2013, 1:53-58.

8. Torlakovic EE, Gomez JD, Driman DK, Parfitt JR, Wang C, Benerjee T, Snover DC: Sessile serrated adenoma (SSA) vs. traditional serrated adenoma (TSA). Am J Surg Pathol 2008, 32:21-29.

9. Terazono K, Yamamoto H, Takasawa S, Shiga K, Yonemura Y, Tochino Y, Okamoto $\mathrm{H}$ : A novel gene activated in regenerating islets. J Biol Chem 1988, 263:2111-2114.

10. Kimura $\mathrm{N}$, Yonekura $\mathrm{H}$, Okamoto $\mathrm{H}$, Nagura $\mathrm{H}$ : Expression of human regenerating gene mRNA and its product in normal and neoplastic human pancreas. Cancer 1992, 70:1857-1863.

11. Watanabe $\mathrm{T}$, Yonekura $\mathrm{H}$, Terazono $\mathrm{K}$, Yamamoto $\mathrm{H}$, Okamoto H: Complete nucleotide sequence of human reg gene and its expression in normal and tumoral tissues. The reg protein, pancreatic stone protein, and pancreatic thread protein are one and the same product of the gene. J Biol Chem 1990, 265:7432-7439.

12. Sekikawa A, Fukui H, Fujii S, Nanakin A, Kanda N, Uenoyama Y, Sawabu T, Hisatsune H, Kusaka T, Ueno S, Nakase H, Seno H, Fujimori T, Chiba T: Possible role of REG la protein in ulcerative colitis and colitic cancer. Gut 2005, 54:1437-1444.

13. Tanaka H, Fukui H, Fujii S, Sekikawa A, Yamagishi H, Ichikawa K, Tomita S, Imura J, Yasuda Y, Chiba T, Fujimori T: Immunohistochemical analysis of REG la expression in ulcerative colitis-associated neoplastic lesions. Digestion 2011, 83:204-209.

14. Sekikawa A, Fukui H, Fujii S, Takeda J, Nanakin A, Hisatsune H, Seno H, Takasawa S, Okamoto H, Fujimori T, Chiba T: REG la protein may function as a trophic and/or anti-apoptotic factor in the development of gastric cancer. Gastroenterology 2005, 128:642-653.

15. Cavard C, Terris B, Grimber G, Christa L, Audard V, Radenen-Bussiere B, Simon MT, Renard CA, Buendia MA, Perret C: Overexpression of regenerating islet-derived 1 alpha and 3 alpha genes in human primary liver tumors with $\beta$-catenin mutations. Oncogene 2006, 25:599-608.

16. Hakata Y, Fukui H, Sekikawa A, Yamagishi H, Ichikawa K, Tomita S, Imura J, Kawamata $H$, Imai $Y$, Fujimori T: Expression of $\beta$-catenin and REG la in relation to cell proliferative ability in salivary gland tumors. Exp Ther Med 2010, 1:437-443

17. Wu JM, Montgomery EA, lacobuzio-Donahue CA: Frequent $\beta$-catenin nuclear labeling in sessile serrated polyps of the colorectum with neoplastic potential. Am J Clin Pathol 2008, 129:416-423.

18. Li L, Fu X, Zhang W, Xiao L, Qiu Y, Peng Y, Shi L, Chen X, Zhou X, Deng M Wnt signaling pathway is activated in right colon serrated polyps correlating to specific molecular form of $\beta$-catenin. Hum Pathol 2013, 44:1079-1088.

19. Pinto $D$, Clevers $H$ : Wnt control of stem cells and differentiation in the intestinal epithelium. Exp Cell Res 2005, 306:357-363.

20. Fukui H, Fujii S, Takeda J, Kayahara T, Sekikawa A, Nanakin A, Suzuki K, Hisatsune H, Seno H, Sawada M, Fujimori T, Chiba T: Expression of Reg la protein in human gastric cancers. Digestion 2004, 69:177-184.

21. Asahara M, Mushiake S, Shimada S, Fukui H, Kinoshita Y, Kawanami C, Watanabe T, Tanaka S, Ichikawa A, Uchiyama Y, Narushima Y, Takasawa S, 
Okamoto H, Tohyama M, Chiba T: Reg gene expression is increased in rat gastric enterochromaffin-like cells following water immersion stress. Gastroenterology 1996, 111:45-55.

22. Naert K, Dupre MP: Large cell neuroendocrine carcinoma arising in a sessile serrated adenoma: a novel observation. Hum Pathol 2012, 43:757-760.

23. Higham AD, Bishop LA, Dimaline R, Blackmore CG, Dobbins AC, Varro A, Thompson DG, Dockray GJ: Mutations of Regla are associated with enterochromaffin-like cell tumor development in patients with hypergastrinemia. Gastroenterology 1999, 116:1310-1318.

24. Sobin LH: Inverted hyperplastic polyps of the colon. Am J Surg Pathol $1985,9: 265-272$

25. Yantiss RK, Goldman H, Odze RD: Hyperplastic polyp with epithelial misplacement (inverted hyperplastic polyp): a clinicopathologic and immunohistochemical study of 19 cases. Mod Pathol 2001, 14:869-875.

26. Kuribayashi K, Ishii T, Ishidate T, Ban N, Hirata Y, Hashida H, Saito K, Iwashiro N, Ohara M, Ishizaka M, Azumad M, Hayashi T, Takayama T: Two cases of inverted hyperplastic polyps of the colon and association with adenoma. Eur I Gastroenterol Hepatol 2004, 16:107-112.

27. Fu K, Fujii T, Kuwayama H, Ishikawa T, Ueda Y, Fujimori T: Invasive cancer arising in a colonic inverted hyperplastic polyp. Endoscopy 2010, 42:29-30.

28. Choi HH, Bae SH, Jang EC, Kim SY, Yeom JO, Lee SY, Chang ED, Cho YS: Intramucosal colon cancer developing in an inverted hyperplastic polyp. Gut Liver 2013, 7:126-127.

doi:10.1186/1746-1596-8-187

Cite this article as: Okamoto et al:: Overexpression of regenerating gene la appears to reflect aberration of crypt cell compartmentalization in sessile serrated adenoma/polyps of the colon. Diagnostic Pathology 2013 8:187.

\section{Submit your next manuscript to BioMed Central and take full advantage of:}

- Convenient online submission

- Thorough peer review

- No space constraints or color figure charges

- Immediate publication on acceptance

- Inclusion in PubMed, CAS, Scopus and Google Scholar

- Research which is freely available for redistribution 